\title{
Niabella tibetensis sp. nov., isolated from soil, and emended description of the genus Niabella
}

\author{
Jun Dai, Fan Jiang, Yang Wang, Bo Yu, Huan Qi, Chengxiang Fang \\ and Congyi Zheng

\section{China Center for Type Culture Collection (CCTCC), College of Life Sciences, Wuhan University,} \\ Wuhan 430072, PR China
}

Correspondence

Chengxiang Fang

cxfang@whu.edu.cn

\begin{abstract}
Strain $15-4^{\top}$, a Gram-stain-negative, rod-shaped, non-motile bacterial strain that produced flexirubin-type pigments, was isolated from Tibet Province, China, and characterized by using a polyphasic taxonomic approach. Phylogenetic analysis based on 16S rRNA gene sequences indicated that the isolate belonged to the family Chitinophagaceae, phylum 'Bacteroidetes', and was related to members of the genus Niabella, with sequence similarities ranging from 94.1 to 96.4\%. Strain $15-4^{\top}$ contained MK-7 as the predominant menaquinone and its DNA G + C content was 46.9 mol\%. The major fatty acids of strain $15-4^{\top}$ were iso- $\mathrm{C}_{15: 0}(41.3 \%)$, iso- $\mathrm{C}_{15: 1}$ $\mathrm{G}(14.9 \%)$, iso- $\mathrm{C}_{17: 0} 3-\mathrm{OH}(13.2 \%)$ and summed feature 3 (comprising $\mathrm{C}_{16: 1} \omega 7 \mathrm{c}$ and/or iso$\left.\mathrm{C}_{15: 0} 2-\mathrm{OH}, 16.0 \%\right)$. These chemotaxonomic data supported the affiliation of strain $15-4^{\top}$ to the genus Niabella. However, a number of physiological and biochemical features enabled the isolate to be differentiated phenotypically from recognized species of the genus Niabella. On the basis of the evidence presented, it is proposed that strain $15-4^{\top}$ represents a novel species, Niabella tibetensis sp. nov.; the type strain is $15-4^{\top}$ (=CCTCC AB $209167^{\top}=N R R L ~ B-59394^{\top}$ ). On the basis of these data, an emended description of the genus Niabella is also proposed.
\end{abstract}

The genus Niabella was first described by Kim et al. (2007) to accommodate Gram-stain-negative, aerobic, non-flagellated and non-gliding, short rod-shaped bacteria that produce flexirubin-type pigments. The genus Niabella belongs to the family Chitinophagaceae, phylum 'Bacteroidetes' (Ludwig et al., 2008), and, at the time of writing, comprised four recognized species, all isolated from soil: Niabella aurantiaca (Kim et al., 2007), N. soli (Weon et al., 2008), N. yanshanensis (Wang et al., 2009) and $N$. ginsengisoli (Weon et al., 2009). During the course of an investigation of the culturable bacterial community in soil from Tibet Province, China, a large number of bacteria were isolated. In this study, the taxonomic characterization of one of these isolates, designated strain $15-4^{\mathrm{T}}$, is reported. On the basis of phenotypic data and phylogenetic inference, the isolate represents a novel species of the genus Niabella.

Strain $15-4^{\mathrm{T}}$ was isolated from a sample taken from the top $20 \mathrm{~cm}$ layer of soil collected from Xietongmen district $\left(88^{\circ} 15^{\prime} \mathrm{E} 29^{\circ} 25^{\prime} \mathrm{N}\right)$. The soil sample was thoroughly suspended in sterilized water and the suspension was spread on R2A agar (Difco) after serial dilution with sterilized water. Isolation was achieved after incubation at $28{ }^{\circ} \mathrm{C}$ for 1 week. Strain $15-4^{\mathrm{T}}$ was cultivated routinely on

The GenBank/EMBL/DDBJ accession number for the 16S rRNA gene sequence of strain $15-4^{\top}$ is GU291295. the same medium at $30{ }^{\circ} \mathrm{C}$ and preserved at $-80{ }^{\circ} \mathrm{C}$ as a suspension in distilled water containing $20 \% \quad(\mathrm{v} / \mathrm{v})$ glycerol.

Cell morphology was examined by using phase-contrast microscopy (BX51; Olympus). Gliding motility was examined as described by Bowman (2000) and Gram staining was performed as described by Gerhardt et al. (1994). In addition to R2A agar, growth of strain $15-4^{\mathrm{T}}$ was tested on trypticase soy broth (TSB; Difco), nutrient agar (NA; Difco) and marine agar 2216 (MA; Difco). Growth conditions were determined by investigating the growth of strain $15-4^{\mathrm{T}}$ at various $\mathrm{pH}(\mathrm{pH} 4-10$, at unit intervals), temperatures $\left(4,10,15,20,30,34\right.$ and $\left.37^{\circ} \mathrm{C}\right)$ and $\mathrm{NaCl}$ concentrations $[0,1,2,3$ and $5 \%(\mathrm{w} / \mathrm{v})]$ on R2A agar for up to 1 week. The $\mathrm{pH}$ was adjusted to between $\mathrm{pH} 4.0$ and 9.0 with stock solutions of $\mathrm{NaHCO}_{3}\left(10 \%\right.$, w/v), $\mathrm{Na}_{2} \mathrm{CO}_{3}$ $(10 \%, \mathrm{w} / \mathrm{v})$ and citrate buffer $(1 \mathrm{M})$, and to $\mathrm{pH} 10.0$ with the buffer system of $\mathrm{Na}_{2} \mathrm{HPO}_{4}(0.05 \mathrm{M})$ and $\mathrm{NaOH}$ $(0.1 \mathrm{M})$. Catalase activity was determined using a $3 \%$ (v/v) hydrogen peroxide solution. Oxidation of $N, N$, $N^{\prime}, N^{\prime}$-tetramethyl- $p$-phenylenediamine was used to determine oxidase activity. Growth under anaerobic conditions was tested on R2A agar in a GasPak (BBL) jar at $30{ }^{\circ} \mathrm{C}$ for 10 days. In order to compare the phenotypic characteristics of strain $15-4^{\mathrm{T}}$ with those of the other species of the genus Niabella, N. aurantiaca KACC $11698^{\mathrm{T}}$, N. soli KACC $12604^{\mathrm{T}}$ and $N$. ginsengisoli GR10-1 ${ }^{\mathrm{T}}$ (obtained from the 
Korean Agricultural Culture Collection, Suwon, Korea) and $N$. yanshanensis CCBAU $05354^{\mathrm{T}}$ (obtained from the China Center for Type Culture Collection, Wuhan, PR China) were used as reference strains. The following tests were performed on the five strains. Hydrolysis of carboxymethylcellulose, casein, chitin and starch was determined using the methods of Smibert \& Krieg (1994). Flexirubin-type pigments were detected by means of a colour shift after exposure of colonies to $20 \%$ (w/v) KOH solution (Reichenbach, 1992). Other biochemical tests were carried out by using API 20NE, API ID 32GN and API ZYM test kits according to the manufacturer's instructions (bioMérieux). The phenotypic features of strain $15-4^{\mathrm{T}}$ are given in the species description and in Table 1.

Chromosomal DNA was isolated and purified by using a Bacteria Genomic DNA isolation kit (ChaoShi-Bio). The $16 \mathrm{~S}$ rRNA gene was amplified by PCR with universal bacterial primers $27 \mathrm{~F}$ and $1527 \mathrm{R}$, which were also used for sequencing (Lane, 1991). An almost-complete 16S rRNA gene sequence of strain $15-4^{\mathrm{T}}$ was obtained and compared with sequences deposited in GenBank. Sequences were aligned using the CLUSTAL_X software (Thompson et al., 1997) and distances were calculated according to Kimura's two-parameter method (Kimura, 1980). Phylogenetic trees were constructed using three tree-making algorithms, i.e. the neighbour-joining, minimum-evolution and maximum-parsimony methods, using MEGA version 3.1 (Kumar et al., 2004).

Analysis of the $16 \mathrm{~S}$ rRNA gene sequence of strain $15-4^{\mathrm{T}}$ resulted in a sequence of $1409 \mathrm{bp}$. Sequence similarity values to recognized members of the genus Niabella were below the threshold for demarcating bacterial species (Stackebrandt \& Goebel, 1994), as follows: N. aurantiaca KACC $11698^{\mathrm{T}}(96.4 \%)$, N. soli KACC $12604^{\mathrm{T}}(95.3 \%), N$. yanshanensis CCBAU $05354^{\mathrm{T}}(94.8 \%)$ and $N$. ginsengisoli GR $10-1^{\mathrm{T}}(94.1 \%)$. No other recognized bacterial species showed more than $95 \%$ 16S rRNA gene sequence similarity to the novel isolate. In the phylogenetic tree based on the neighbour-joining algorithm, strain $15-4^{\mathrm{T}}$ was clearly placed within the genus Niabella, forming a separate branch with $N$. aurantiaca KACC $11698^{\mathrm{T}}$ (Fig. 1). The maximum-parsimony and minimum-evolution phylogenetic trees showed essentially the same topology (data not shown). These results suggest that strain $15-4^{\mathrm{T}}$ represents a novel species within the genus Niabella.

The DNA G + C content of strain $15-4^{\mathrm{T}}$ was determined by using HPLC according to the method of Mesbah et al. (1989). Isoprenoid quinones were extracted and identified by HPLC as described by Xie \& Yokota (2003). To determine the whole-cell fatty acid profile, strain $15-4^{\mathrm{T}}$ and

Table 1. Differential characteristics of strain $15-4^{\top}$ and other species of the genus Niabella

Strains: $1,15-4^{\mathrm{T}} ; 2$, N. aurantiaca KACC $11698^{\mathrm{T}}$; 3, N. soli KACC $12604^{\mathrm{T}} ; 4$, N. ginsengisoli GR $10-1^{\mathrm{T}}$; 5 , N. yanshanensis CCBAU $05354^{\mathrm{T}}$. All strains are positive for production of flexirubin-type pigments, assimilation of D-glucose, L-arabinose, D-mannose, $N$-acetylglucosamine, maltose, L-rhamnose, sucrose, salicin and melibiose, aesculin hydrolysis and $\beta$-galactosidase activity. All strains are negative for gliding motility, nitrate reduction, glucose acidification, arginine dihydrolase and urease. All data are from this study except the DNA G + C content of the four reference strains [taken from Kim et al. (2007), Weon et al. (2008, 2009) and Wang et al. (2009)]. +, Positive; -, negative; (+), weakly positive.

\begin{tabular}{|lccccc|}
\hline Characteristic & $\mathbf{1}$ & $\mathbf{2}$ & $\mathbf{3}$ & $\mathbf{4}$ & $\mathbf{5}$ \\
\hline Highest NaCl concentration tolerated (\%) & 1.0 & 3.0 & 1.0 & 2.0 & 1.0 \\
Catalase/oxidase activities & $+/+$ & $+/-$ & $-/+$ & $+/-$ & $+/+$ \\
Casein hydrolysis & + & + & - & - & + \\
Gelatin hydrolysis & - & - & - & - & + \\
Indole production & + & + & + & - & + \\
Assimilation of (API ID 32GN): & & & & & \\
Glycogen & - & - & - & - & + \\
Malic acid & - & - & - & - & + \\
D-Mannitol & - & - & + & - & + \\
Phenylacetic acid & - & - & - & - & + \\
Potassium gluconate & - & - & - & - & + \\
D-Ribose & + & - & + & + & + \\
Trisodium citrate & - & - & - & - & + \\
Enzyme activity (API ZYM): & & & & & \\
Cystine arylamidase & $(+)$ & - & $(+)$ & - & + \\
$\alpha$-Mannosidase & $(+)$ & - & - & $(+)$ & + \\
Trypsin & - & - & - & - & + \\
Valine arylamidase & - & - & - & - & + \\
DNA G+C content (mol\%) & 46.9 & 45 & 45 & 43 & 42 \\
\end{tabular}




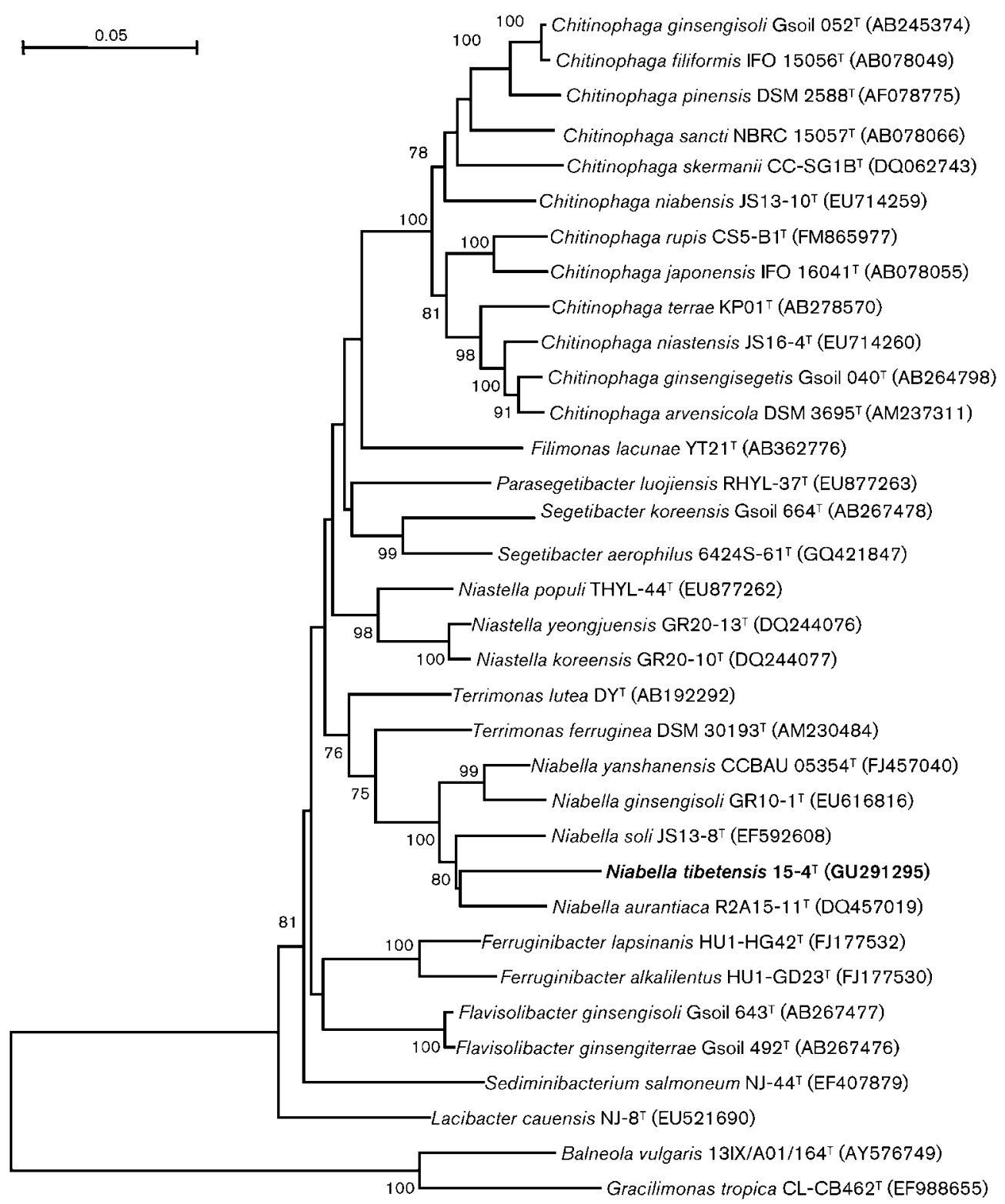

Fig. 1. Neighbour-joining phylogenetic tree based on $16 \mathrm{~S}$ rRNA gene sequences showing the relationships of strain $15-4^{\top}$ and representative members of the family Chitinophagaceae. Only bootstrap values (percentages of 1000 replications) $\geqslant 70 \%$ are shown at nodes. Balneola vulgaris $13 \mathrm{IX} / \mathrm{A01} / 164^{\top}$ and Gracilimonas tropica CL-CB462 ${ }^{\top}$ were used as the outgroup. Bar, 0.05 substitutions per nucleotide position.

the four reference strains were grown on R2A agar at $30{ }^{\circ} \mathrm{C}$ for $48 \mathrm{~h}$. Analysis of fatty acid methyl esters was carried out using GC (6890; Hewlett Packard) according to the instructions of the Sherlock Microbial Identification System (MIDI).

The DNA G + C content of strain $15-4^{\mathrm{T}}$ was $46.9 \mathrm{~mol} \%$, a value that was slightly higher than those reported for the other species of the genus Niabella (Table 1). The predominant isoprenoid quinone was MK-7, which is in line with that found in all members of the family Chitinophagaceae. The major fatty acids of strain $15-4^{\mathrm{T}}$ were iso- $\mathrm{C}_{15: 0}(41.3 \%)$, iso- $\mathrm{C}_{15: 1} \mathrm{G}(14.9 \%)$, iso- $\mathrm{C}_{17: 0}$
3-OH (13.2\%) and summed feature 3 (comprising $\mathrm{C}_{16: 1} \omega 7 c$ and/or iso- $\left.\mathrm{C}_{15: 0} 2-\mathrm{OH}, 16.0 \%\right)$. As shown in Table 2, the fatty acid compositions of strain $15-4^{\mathrm{T}}, N$. aurantiaca KACC $11698^{\mathrm{T}}, N$. soli KACC $12604^{\mathrm{T}}, N$. yanshanensis CCBAU $05354^{\mathrm{T}}$ and $N$. ginsengisoli GR10-1 ${ }^{\mathrm{T}}$ were very similar, with only minor differences in the respective proportions of some components.

Based on phylogenetic inference and phenotypic data, strain $15-4^{\mathrm{T}}$ represents a novel species of the genus Niabella, for which the name Niabella tibetensis sp. nov. is proposed. As a consequence of newly reported characteristics, an emended description of the genus Niabella is given. 
Table 2. Fatty acid profile of strain $15-4^{\top}$ and other members of the genus Niabella

Strains: $1,15-4^{\mathrm{T}} ; 2$, N. aurantiaca KACC $11698^{\mathrm{T}}$; 3, N. soli KACC $12604^{\mathrm{T}} ; 4, \quad N$. ginsengisoli GR10-1 ${ }^{\mathrm{T}} ; 5, N$. yanshanensis CCBAU $05354^{\mathrm{T}}$. Values are percentages of total fatty acids. All data are from this study. Fatty acids amounting to $<0.5 \%$ of the total fatty acids in all strains listed are not shown. tr, Trace $(<0.5 \%)$; ND, not detected.

\begin{tabular}{|c|c|c|c|c|c|}
\hline Fatty acid & 1 & 2 & 3 & 4 & 5 \\
\hline $\mathrm{C}_{14: 0}$ & 0.8 & 0.6 & 0.6 & 1.1 & 1.3 \\
\hline iso- $\mathrm{C}_{15: 1} \mathrm{G}$ & 14.9 & 17.7 & 13.0 & 23.8 & 24.5 \\
\hline iso- $\mathrm{C}_{15: 0}$ & 41.3 & 34.4 & 44.2 & 35.2 & 34.8 \\
\hline anteiso- $\mathrm{C}_{15: 0}$ & 0.9 & 1.3 & 1.3 & 0.5 & $\operatorname{tr}$ \\
\hline iso- $\mathrm{C}_{16: 0}$ & $\operatorname{tr}$ & $\operatorname{tr}$ & $\mathrm{ND}$ & 1.3 & 0.6 \\
\hline $\mathrm{C}_{16: 0}$ & 3.4 & 3.6 & 3.4 & 3.7 & 4.1 \\
\hline iso- $\mathrm{C}_{15: 0} 3-\mathrm{OH}$ & 2.4 & 2.4 & 2.1 & 3.8 & 3.1 \\
\hline $\mathrm{C}_{15: 0} 2-\mathrm{OH}$ & 0.5 & 2.5 & 1.4 & $\mathrm{ND}$ & $\operatorname{tr}$ \\
\hline iso- $\mathrm{C}_{16: 0} 3-\mathrm{OH}$ & 0.7 & $\mathrm{ND}$ & $\mathrm{ND}$ & 0.9 & 0.5 \\
\hline $\mathrm{C}_{15: 0} 3-\mathrm{OH}$ & ND & 0.5 & $\mathrm{ND}$ & ND & ND \\
\hline $\mathrm{C}_{16: 0} 2-\mathrm{OH}$ & ND & 0.7 & $\mathrm{ND}$ & 0.5 & $\operatorname{tr}$ \\
\hline $\mathrm{C}_{16: 0} 3-\mathrm{OH}$ & 3.3 & 3.0 & 2.0 & 2.9 & 1.7 \\
\hline iso- $\mathrm{C}_{17: 0} 3-\mathrm{OH}$ & 13.2 & 15.2 & 13.9 & 12.6 & 14.2 \\
\hline $\mathrm{C}_{17: 0} 2-\mathrm{OH}$ & $\operatorname{tr}$ & 0.6 & 0.5 & ND & $\mathrm{ND}$ \\
\hline $\mathrm{C}_{17: 0} 3-\mathrm{OH}$ & $\mathrm{ND}$ & 1.2 & 0.6 & $\mathrm{ND}$ & $\mathrm{ND}$ \\
\hline Summed feature $3^{*}$ & 16.0 & 14.1 & 15.0 & 10.2 & 10.2 \\
\hline Unknown $13.565 \dagger$ & 0.9 & 0.9 & 1.0 & 0.6 & 0.5 \\
\hline Unknown $16.582 \dagger$ & 1.7 & 1.4 & 1.2 & 0.9 & 1.2 \\
\hline
\end{tabular}

*Summed features represent groups of two or three fatty acids that could not be separated by GLC with the MIDI system. Summed feature 3 contains $\mathrm{C}_{16: 1} \omega 7 c$ and/or iso- $\mathrm{C}_{15: 0} 2-\mathrm{OH}$.

$\dagger$ Unknown fatty acids have no name listed in the peak library file of the MIDI system and therefore cannot be identified; values are equivalent chain-lengths.

\section{Emended description of the genus Niabella Kim et al. 2007}

This emended description takes into account results from Kim et al. (2007), Weon et al. $(2008,2009)$ and Wang et al. (2009), together with those from this study.

Cells are Gram-stain-negative, strictly aerobic, nonflagellated, non-gliding, non-spore-forming, short rods. Flexirubin-type pigments are produced. Catalase and oxidase activities are species-dependent. The predominant isoprenoid quinone is MK-7. The major fatty acids are iso$\mathrm{C}_{15: 0}$, iso- $\mathrm{C}_{15: 1} \mathrm{G}$, iso- $\mathrm{C}_{17: 0} 3-\mathrm{OH}$ and summed feature 3 (comprising iso- $\mathrm{C}_{15: 0} 2-\mathrm{OH}$ and/or $\mathrm{C}_{16: 1} \omega 7 \mathrm{c}$ ). The DNA $\mathrm{G}+\mathrm{C}$ contents are approximately $42-47 \mathrm{~mol} \%$. Phylogenetically, the genus is a member of the phylum 'Bacteroidetes'. The type species is Niabella aurantiaca.

\section{Description of Niabella tibetensis sp. nov.}

Niabella tibetensis (ti.be.ten'sis. N.L. fem. adj. tibetensis of or belonging to Tibet, an autonomous region in north-west China).
Cells are strictly aerobic, short rods, $0.5-0.8 \mu \mathrm{m}$ in diameter and 1.1-1.7 $\mu \mathrm{m}$ in length, which are nonflagellated, non-gliding and Gram-stain-negative. Growth occurs on R2A agar after incubation at $30{ }^{\circ} \mathrm{C}$ for $48 \mathrm{~h}$. Good growth also occurs on TSA and NA, but not on MA. Colonies on R2A agar are orange, convex and circular, with regular margins. Growth occurs with $0-1 \% \mathrm{NaCl}(\mathrm{w} / \mathrm{v})$, at $15-34{ }^{\circ} \mathrm{C}$ (optimum, $25-30{ }^{\circ} \mathrm{C}$ ) and at $\mathrm{pH} 5.0-8.0$ (optimum, pH 6.0-7.0). Produces flexirubin-type pigments. Catalase and oxidase activities are present. Hydrolyses casein, but not chitin, carboxymethylcellulose, DNA or starch. Positive for indole production, aesculin hydrolysis and $\beta$-galactosidase activity, but negative for nitrate reduction, glucose fermentation, arginine dihydrolase, urease and gelatin hydrolysis (API 20NE). Alkaline phosphatase, esterase (C4), esterase lipase (C8), leucine arylamidase, cystine arylamidase, acid phosphatase, naphthol-ASBI-phosphohydrolase, $\alpha$-galactosidase, $\beta$-galactosidase, $\alpha$-glucosidase, $\beta$-glucosidase, $N$-acetyl- $\beta$-glucosaminidase, $\alpha$-mannosidase and $\alpha$-fucosidase activities are present, but lipase (C14), valine arylamidase, trypsin, $\alpha$-chymotrypsin and $\beta$-glucuronidase activities are absent (API ZYM). D-Glucose, L-arabinose, D-mannose, $\mathrm{N}$-acetylglucosamine, maltose, L-rhamnose, D-ribose, sucrose, salicin and melibiose are assimilated (API 20NE and API ID 32GN). D-Mannitol, potassium gluconate, capric acid, adipic acid, malic acid, trisodium citrate, phenylacetic acid, inositol, itaconic acid, suberic acid, sodium malonate, sodium acetate, lactic acid, L-alanine, potassium 5-ketogluconate, glycogen, 3-hydroxybenzoic acid, L-serine, L-fucose, D-sorbitol, propionic acid, valeric acid, L-histidine, potassium 2-ketogluconate, 3-hydroxybutyric acid, 4-hydroxybenzoic acid and L-proline are not assimilated. The predominant isoprenoid quinone is MK-7. The major cellular fatty acids $(>13 \%)$ are iso- $\mathrm{C}_{15: 0}$, iso- $\mathrm{C}_{15: 1} \mathrm{G}$, iso$\mathrm{C}_{17: 0} 3-\mathrm{OH}$ and summed feature 3 (comprising $\mathrm{C}_{16: 1} \omega 7 c$ and/or iso- $\left.\mathrm{C}_{15: 0} 2-\mathrm{OH}\right)$.

The type strain is $15-4^{\mathrm{T}}\left(=\mathrm{CCTCC}\right.$ AB $209167^{\mathrm{T}}=\mathrm{NRRL}$ B-59394 ${ }^{\mathrm{T}}$ ), isolated from the surface layer of a desert soil from Tibet Province, China. The DNA G $+\mathrm{C}$ content of the type strain is $46.9 \mathrm{~mol} \%$.

\section{Acknowledgements}

This work was supported by the R \& D Infrastructure and Facility Development Program from the Ministry of Science and Technology of the People's Republic of China (grant no. 2005DKA21208).

\section{References}

Bowman, J. P. (2000). Description of Cellulophaga algicola sp. nov., isolated from the surfaces of Antarctic algae, and reclassification of Cytophaga uliginosa (ZoBell and Upham 1944) Reichenbach 1989 as Cellulophaga uliginosa comb. nov. Int J Syst Evol Microbiol 50, 18611868.

Gerhardt, P., Murray, R. G. E., Wood, W. A. \& Krieg, N. R. (editors) (1994). Methods for General and Molecular Bacteriology. Washington, DC: American Society for Microbiology. 
Kim, B. Y., Weon, H.-Y., Yoo, S.-H., Hong, S.-B., Kwon, S.-W., Stackebrandt, E. \& Go, S.-J. (2007). Niabella aurantiaca gen. nov., sp. nov., isolated from a greenhouse soil in Korea. Int $J$ Syst Evol Microbiol 57, 538-541.

Kimura, M. (1980). A simple method for estimating evolutionary rates of base substitutions through comparative studies of nucleotide sequences. J Mol Evol 16, 111-120.

Kumar, S., Tamura, K. \& Nei, M. (2004). MEGA3: Integrated software for molecular evolutionary genetics analysis and sequence alignment. Brief Bioinform 5, 150-163.

Lane, D. J. (1991). 16S-23S rRNA sequencing. In Nucleic Acid Techniques in Bacterial Systematics, pp. 125-175. Edited by E. Stackebrandt \& M. Goodfellow. Chichester: Wiley.

Ludwig, W., Euzéby, J. \& Whitman, W. B. (2008). Draft Taxonomic Outline of the Bacteroidetes, Planctomycetes, Chlamydiae, Spirochaetes, Fibrobacteres, Fusobacteria, Acidobacteria, Verrucomicrobia, Dictyoglomi and Gemmatimonadetes for Volume 4 of the second edition of Bergey's Manual of Systematic Bacteriology. (http://www.bergeys.org/outlines. html)

Mesbah, M., Premachandran, U. \& Whitman, W. B. (1989). Precise measurement of the $\mathrm{G}+\mathrm{C}$ content of deoxyribonucleic acid by highperformance liquid chromatography. Int J Syst Bacteriol 39, 159167.

Reichenbach, H. (1992). The order Cytophagales. In The Prokaryotes, 2nd edn, vol. 4, pp. 3631-3675. Edited by A. Balows, H. G. Trüper, M. Dworkin, W. Harder \& K. H. Schleifer. New York: Springer.
Smibert, R. M. \& Krieg, N. R. (1994). Phenotypic characterization. In Methods for General and Molecular Bacteriology, pp. 607-654. Edited by P. Gerhardt, R. G. E. Murray, W. A. Woods \& N. R. Krieg. Washington, DC: American Society for Microbiology.

Stackebrandt, E. \& Goebel, B. M. (1994). Taxonomic note: a place for DNA-DNA reassociation and 16S rRNA sequence analysis in the present species definition in bacteriology. Int J Syst Bacteriol 44, 846849.

Thompson, J. D., Gibson, T. J., Plewniak, F., Jeanmougin, F. \& Higgins, D. G. (1997). The CLUSTAL_X windows interface: flexible strategies for multiple sequence alignment aided by quality analysis tools. Nucleic Acids Res 25, 4876-4882.

Wang, H., Zhang, Y. Z., Man, C. X., Chen, W. F., Sui, X. H., Li, Y., Zhang, X. X. \& Chen, W. X. (2009). Niabella yanshanensis sp. nov., isolated from the soybean rhizosphere. Int J Syst Evol Microbiol 59, 2854-2856.

Weon, H. Y., Kim, B.-Y., Joa, J.-H., Kwon, S.-W., Kim, W.-G. \& Koo, B.-S. (2008). Niabella soli sp. nov., isolated from soil from Jeju Island, Korea. Int J Syst Evol Microbiol 58, 467-469.

Weon, H. Y., Yoo, S.-H., Kim, B.-Y., Son, J.-A., Kim, Y.-J. \& Kwon, S.-W. (2009). Niabella ginsengisoli sp. nov., isolated from soil cultivated with Korean ginseng. Int J Syst Evol Microbiol 59, 12821285.

Xie, C. H. \& Yokota, A. (2003). Phylogenetic analyses of Lampropedia hyalina based on the 16S rRNA gene sequence. J Gen Appl Microbiol 49, 345-349. 